\title{
Pengaruh Kinerja Baznas Terhadap Kesejahteraan Masyarakat di Indonesia Tahun 2001-2020
}

\author{
Shimah Fauziah Yeubun ${ }^{* 1}$, Indah Yuliana ${ }^{2}$ \\ 1,2Magister Ekonomi Syariah \\ UIN Maulana Malik Ibrahim \\ Malang, Indonesia
}

\section{e-mail: zhimafauzia@gmail.com¹, indahoty@manajemen.uin-malang.ac.id²}

Pengutipan

Yeubun, S,F.\& Yuliana,I. (2021). Pengaruh Kinerja Baznas Terhadap Kesejahteraan Masyarakat di Indonesia Tahun 2001-2020. Jurnal Pendidikan Ekonomi Undiksha, 13(2), 385-393

http://dx.doi.org/1 $0.23887 /$ jjpe.v13i2 .40801

\begin{abstract}
Abstrak
Riwayat Artikel Tanggal diajukan: 30 Oktober 2021

Tanggal diterima 15 November 2021

Tanggal dipublikasikan: 15 Desember 2021

Penelitian ini bertujuan untuk meneliti terkait dengan kinerja Badan Amil Zakat Nasional (BAZNAS) yang merupakan lembaga pengelolah dana zakat terhadap kesejahteraan masyarakat di Indonesia. Pengukuran kinerja dengan menghitung rasio fiscal performance, public support, dan efficiency fundraising. Selain iu, kesejahteraan masyarakat dengan melihat angka Indeks Pembangunan Manusia (IPM). Metode penelitian yang digunakan adalah adalah kuantitatif deskriptif dengan jenis data sekunder yaitu laporan keuangan BAZNAS dan angka IPM dengan periode pengamatan selama tahun 2001 hingga 2020. Teknik analisis data dengan menggunakan regresi linear berganda dengan alat statistic eviews 12 . Hasil penelitian menunjukan bahwa fiscal performance, public support dan efficiency fundrising tidak berpengaruh secara parsial terhadap kesejahteraan masyarakat di Indonesia. Selanjutnya uji simultan menunjukan kinerja BAZNAS yang terdiri dari fiscal performance, public support dan efficiency fundrising tidak berpengaruh secara simultan terhadap kesejahteraan masyarakat di Indonesia.
\end{abstract}

Kata Kunci: BAZNAS; IPM; Kinerja

\section{Abstract}

This study aims to examine the performance of the National Amil Zakat Agency (BAZNAS) which is an institution that manages zakat funds for the welfare of the people in Indonesia. Performance measurement by calculating the ratio of fiscal performance, public support, and efficiency of fundraising. In addition, people's welfare by looking at the Human Development Index (IPM). The research method used is descriptive quantitative with secondary data types, namely BAZNAS financial statements and HDI figures with an observation period from 2001 to 2020. The data analysis technique uses multiple linear regression with statistical evaluation tools 12. The results show that fiscal performance, public support, and efficiency fundraising do not partially affect the welfare of the people in Indonesia. Furthermore, the simultaneous test shows that the performance of BAZNAS which consists of fiscal performance, public support, and efficiency funding does not simultaneously affect the welfare of the people in Indonesia.

Keywords : BAZNAS; HDI; Performance 


\section{PENDAHULUAN}

Kesejahteraan sosial secara konseptual memiliki subtansi yang sama dalam pengertiannya namun, memiliki berbagai makna yang relatif berbeda. Menurut Suradi Suatu keadaan atau kondisi kehidupan manusia yang terbentuk ketika berbagai permasalahan sosial dapat dikelola dengan baik dan ketika manusia mampu untuk memenuhi kebutuhan serta memiliki kesempatan sosial dengan pemanfaatan semakismal mungkin inilah yang terdefinisikan sebagai kesejahteraan sosial (Suradi, 2017).

Beberapa hal yang perlu digarisbawahi ialah pertama, kesejahteraan sosial adalah hak bagi setiap warga negara, kedua kesejahteraan sosial menjadi tujuan akhir dari pembangunan nasional, bersama-sama dijalankan oleh masyarakat dan ketiga, kinerja pembangunan nasional merupakan indikator dari kesejahteraan sosial. Oleh karena itu, jika kesejahteraan sosial dapat terealisasikan, maka hal ini menggambarkan keberhasilan negara dalam penyelenggaraan pembangunan nasional, demikian pula sebaliknya. Ini menujukkan bahwa pembangunan kesejahreaan sosal tidak kalah strategisnya dalam pembangunan ekonomi, politik, pertahanan dan keamanan. Komponen ini tidak dapat diwujudkan apabila jumlah penduduk miskin, pengangguran dan angka putus sekolah cukup tinggi, kesengjangan sosial ekonomi dapat menyebabkan konflik sosial yang meluas sehingga perilaku anti sosial tidak dapat dikendalikan, inilah mengapa posisi pembangunan kesejahteraan sosial menduduki posisi strategis dalam pembangunan sektoral (Sodiq, 2016). ndeks pembangunan manusia (IPM) telah menjadi alat ukur yang tepat untuk melihat atau mengukur kesejahteraan nasyarakat secara umum. Indeks ini menangkap perkembangan di sektor ekonomi dan sektor sosial sekaligus sehingga dapat menggambarkan capaian disektor kesejahteraan masyarakat secara agregat (Statistik, 2020)(Purbaningsih, 2021). Indeks pembangunan manusia digunakan untuk mengklasifikasikan apakah suatu negara dapat dikatakan menjadi negara maju atau negara berkembang. (Ningrum, Khairunnisa, \& Huda, 2020; Prihastuti, 2018)

Gambar 1

Perkembangan Indeks Pembangunan Manusia di Indonesia

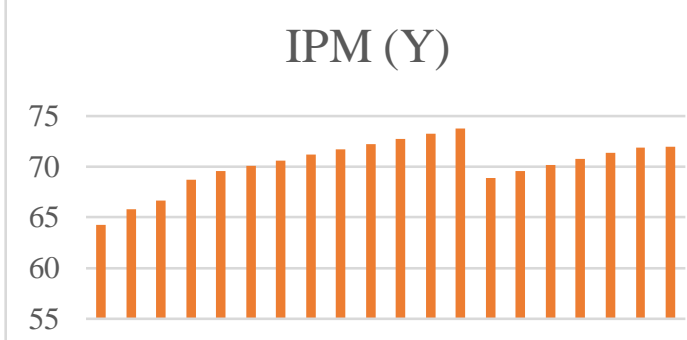

Sumber : Badan Pusat Statistik Berbagai upaya pemerintah yang dilakukan untuk meningkatkan kesejahteraan masyarakat nyatanya belum menunjukkan hasil yang signfikan, terlihat presentase IPM mengalami fluktuatif sepanjang tahun. Pemerintah berhasil melalui program-programnya menaikkan IPM sebesar 74\% pada tahun 2013. Meskipun setelahnya IPM mengalami penurunan drastis pada $68,90 \%$ pada tahun 2014 sekaligus IPM terendah sepanjang 20 tahun terakhir.

Program pemerintah terus di luncurkan untuk meningkatkan IPM melalui anggaran-anggaran khusus guna mendorong laju pembangunan ekonomi pada sektor-sektor keuangan publik dan sektor sosial. Namun, hal tersebut belum mampu secara nyata meningkatkan kesejahteraan sosial. Untuk itu diperlukan perhatian khusus kepada instrumentinstrument yang telah ada agar mampu berkontribusi lebih baik dalam menunjang pergerakan sektor rill dalam hal ini instrument zakat. Dana zakat dianggap sebagai salah satu sumber dana terpenting yang tersedia dalam sistem ekonomi dan keuangan Islam (Suprayitno Eko, Mohamed Aslam, \& Azhar Harun, 2017).

Zakat menjadi salah satu instrument pembangunan manusia paling berperan khususnya di Indonesia. $\mathrm{Hal}$ ini dikarenakan zakat memiliki dua konsep utama dalam pertumbuhan ekonomi berkeadilan dan mekanisme sharing dalam perekonomian sehingga kajan-kajian 
p-ISSN : 2599-1418

e-ISSN : 2599-1426

dimensi diatas telah dilakukan dimana mengindikasikan hiubungan positif dengan pengukuran pembangunan manusia (Rina Murniati \& Beik, 2014).

Ekonomi Islam memandang keberhasilan pertumbuhan ekonomi tidak hanya terkait dengan pencapaian nilai materi, tetapi juga dari segi peningkatan kehidupan keagamaan, sosial dan kemasyarakatan. (Achiria, 2018); (Haron \& Rahman, 2016).

\section{Tabel 1}

Total Penghimpunan zakat, Penyaluran dan Presentase kesejahteraan penduduk Tahun 2001-2020

\begin{tabular}{ccc}
\hline Tahun & $\begin{array}{c}\text { Penghimpunan } \\
\text { Zakat } \\
(\mathrm{Rp})\end{array}$ & $\begin{array}{c}\text { Penyaluran } \\
\text { Zakat } \\
(\mathrm{Rp})\end{array}$ \\
\hline 2001 & $120,694,549$ & 0.00 \\
2002 & $288,643,66+61$. & $99,895,146$ \\
2003 & 1.307 .300 .388 & 488.689 .375 \\
2004 & $2,224,208,946$ & $1,486,305,685$ \\
2005 & 20.026 .660 .485 & 18.269 .202 .489 \\
2006 & 20.026 .660 .485 & 20.080 .389 .801 \\
2007 & $14.592 .0 \mathrm{~L} 6.646$ & 18.293 .112 .192 \\
2008 & $19.57 \mathrm{~L} .494 .91$ & 12.984 .077 .1241 \\
2009 & 26.377 .107 .112 & 21.474 .642 .696 \\
2010 & 33.125 .920 .075 & 38.526 .616 .319 \\
2011 & 44.168 .593 .929 & 49.801 .980 .256 \\
2012 & 40.387 .972 .149 & 36.019 .79 .930 \\
2013 & 50.741 .735 .215 & 45.068 .566 .496 \\
2014 & 69.865 .506 .671 & 64.265 .141 .159 \\
2015 & 82.272643 .293 & 66.766 .033 .369 \\
2016 & 97.637 .657 .910 & 67.727 .019 .807 \\
2017 & 138.096 .290 .551 & 118.071 .046 .770 \\
2018 & 153.153 .229 .174 & 191.966 .485 .358 \\
2019 & 248.342 .677 .327 & 225.702 .309 .429 \\
2020 & 305.347 .256 .942 & 290.141 .453 .285 \\
\hline
\end{tabular}

Sumber : Laporan Keuangan BAZNAS Data penghimpunan dan penyaluran zakat diperoleh dari BAZNAS Pusat, Provinsin dan Kabupaten/Kota yang dibantu dengan sistem IT SIMBA BAZNAS. Sistem ini memfasilitasi sistem pelaporan zakat yang terintegrasi satu pintu dari setiap OPZ ke BAZNAS pusat. Berdasarkan tabel diatas sepanjang 20 tahun terakhir (2001-2020) penghimpunan zakat selalu meingkat. Jumlah penghimpunan terbesar berada pada tahun 2020 sebesar Rp 305.347.256.942. Jumlah terendah setelah diberlakukanya sistem IT SIMBA ialah pada tahun 2012 sebesar
Jurnal Pendidikan Ekonomi Undiksha

Vol.13 No.2 (2021)

40.387.972.149. Pada tahun tersebut fasilitas pendukung dalam pelaporan masih pada tahap awal sehingga belum berjalan dengan semestinya. (Djuwarijah, 2008; Ezza, S, \& Setiawan, 2018).

Tabel 1 menunjukkan presentase kesejahteraan penduduk dari tahun ke tahun mengalami pergerakan yang signifikan terutama pada tahun 2015 dimana IPM menurun drastis berbanding terbalik dengan penghimpunan serta penyaluran zakat yang terus tumbuh. Hal ini menunjukkan adanya gap pada penelitian-penelitian lain yang membuktikan secara teoritical dan empiris bahwa zakat sebagai instrumen pembangunan ekonomi mampu meningkatkan kesejahteraan penduduk. (Arwani \& Wahdati, 2020; Eko, Aslam, \& Harun, 2017; R Murniati \& Beik, 2014; Nurzaman, 2011, 2017) berbanding terbalik dengan (Khasandy \& Badrudin, 2019) menunjukkan bahwa zakat di Indonesia tidak berpengaruh terhadap pertumbuhan ekonomi dan kesejahteraan masyarakat.

Penghimpunan dan penyaluran zakat yang telah menjadi tugas OPZ kepada mustahik seharusnya mampu memberikan manfaat yang signifikan. Oleh karena itu maka perlu adanya pengukuran kinerja OPZ agar tujuan kesejahteraan masyarakat dapat terwujud. Dalam mengevaluasi kinerja lembaga non profit terdapat berbagai pengukuran dengan pendekatan rasio (Azwari, Rijal, Safitri, \& Saputra, 2019; Bahri, Romantin, \& Lubis, 2017; Lazuardy, Sarumpaet, \& Sukmasari, 2017; Rithie \& Kolodinsky, 2003; Sekeenah Anuar, Mohd, \& Ariffin, 2019). Berdasarkan hal ini peneltian ingin mengkaji pengaruh kinerja keuangan yang di proksikan oleh pendekatan rasio Ritcie \& Kolodinsky diantaranya fiscal performance, public support dan fundraising efficiency terhadap peningkatan presentase kesejahteraan masyarakat di Indonesia selama 20 tahun terakhir (2001-2020).

Kinerja fiskal rasio merupakan suatu rasio yang menunjukkan seberapa besar penerimaan atau pendapatan suatu organisasi nirlaba (Rithie \& Kolodinsky, 2003). Kinerja fiskal pada OPZ dikatakan baik atau sehat jika nilai rasionya diatas 1,0 
(Sanders, 2008). Hubungan positif antara fiscal performance dengan besarnya penyaluran zakat atau memiliki hubungan berbanding lurus telah dibuktikan oleh (Bahri et al., 2017). BAZNAS sendiri terus mengoptimalkan pendayagunaan penyaluran zakat untuk menekan angka kemiskinan, meningkatkan kesejahteraan dan mempersempit kesenjangan sosial yang ada (BAZNAS, 2020). Namun hal tersebut secara empiris masih menjadi kontradiktif di beberapa penelitian. Lembaga zakat umumnya harus memiliki kinerja fiskal yang baik guna mendapatkan kepercayaan masyarakat. Karena hal ini menunjukkan bahwa lembaga zakat mampu bertahan dan dapat menjalankan program-program penyaluran zakat dengan optimal. Selain itu, kinerja fiskal dalam pelaksanaan tanggung jawab dapat membantu organisasi dalam mencapai eksistensi dan misi yang lebih sempurna untuk dapat memaksimalkan kontribusinya. Sehingga solusi yang ditawarkan ialah lembaga pengelola zakat harus memiliki reputasi yang baik dengan melihat kualitas pengelolaan zakat, diukur dengan kinerjanya (Ayu, Cahya, \& Achmad, 2017; Wahab \& Rahim, 2011; Wahab, Zainol, Bakar, Ibrahim, \& Minhaj, 2016) dengan demikian terjadi pengaruh liniear antara fiscal performance terhadap penyaluran zakat guna meningkatkan kesejahteraan.

H1 : Apakah Terdapat Pengaruh kebijakan fiskal terhadap tingkat kesejahteraan masyarakat di Indonesia pada tahun 2001-2020.

Non profit Organization (NPO) seperti halnya lembaga zakat harus diukur kinerjanya untuk mengevaluasi sudah sejauh mana tujuan dan misi dan OPZ tersebut dapat tercapai sehingga meningkatkan ekonomi masyarakat dapat terwujud serta mendapatkan kepercayaan masyarakat. Dukungan publik digunakan sebagai sinyal terkait tingkat ketergantungan organisasi. Biasanya masyarakat cenderung lebih memlih berzakat pada OPZ yang memiliki tingkat ketergantungan yang rendah. Dengan demikian masyarakat yang ingin memberikan kontribusinya akan cenderung memilih OPZ dengan kinerja keuangan yang sehat (Lazuardy et al., 2017) (Ayu et al., 2017) Pemasukan dana pada BAZNAS tidak hanya bersumber dari para donatur atau masyarakat, Kementerian Agama melalui dana APBN juga menjadi sumber pendapatan OPZ. Dengan demikian, terdapat pengaruh liniear antara public support terhadap penyaluran zakat guna smendorong kesejahteraan masyarakat. (Bahri et al., 2017; R Murniati \& Beik, 2014; Nurzaman, 2011, 2017; Rithie \& Kolodinsky, 2003).

$\mathrm{H} 2$ : Apakah terdapat pengaruh dukungan publik terhadap tingkat kesejahteraan masyarakat di Indonesia pada tahun 2001-2020.

Efisiensi program menjadi bagian kinerja keuangan yang menggambarkan seberapa efisiensi aktivitas operasi yang dijalankan suatu organisasi nirlaba. Variabel ini menunjukkan seberapa besar presentase beban yang dikeluarkan dalam menjalankan program. Hal ini dapat menjadi sinyal kepada masyarakat seberapa efektif pemanfaatan dana yang telah dizakatkan. Sehingga terciptanya kepercayaan masyarakat terhadap OPZ (Ayu et al., 2017; Wahab et al., 2016) Melalui rasio ini muzaki dapat mengetahui seefisiensi apakah zakat yang dikeluarkan digunakan untuk mencapai tujuan dan misi dari OPZ ataukah semata-mata hanya membiayai biaya operasional lembaga. (Wahab \& Rahim, 2011) menjelaskan semakin efisien dan efektif suatu lembaga, maka output yang dihasilkan atau manfaat yang diterima oleh masyarakat semakin besar, sehingga berpeluang besar untuk terwujudnya peningkatan kesejahteraan masyarakat dapat terwujud. Kinerja keuangan yang baik akan menghasilkan kontribusi yang baik pula dari para muzaki. Berdasarkan hal tersebut terdapat pengaruh linier antara efisiensi program terhadap tingkat kesejahteraan masyarakat. (Bahri et al., 2017; R Murniati \& Beik, 2014; Nurzaman, 2011, 2017; Rithie \& Kolodinsky, 2003).

H3: Apakah terdapat pengaruh fundraising
efficiency terhadap tingkat
kesejahteraan masyarakat di
Indonesia pada tahun 2001-2020.




\section{METODE PENELITIAN}

Penelitian ini merupakan penelitian deskriptif kuantitatif. Penelitian ini untuk menguji hipotesis berkaitan dnegan pengaruh kinerja keuangan yang diproksikan oleh rasio fiskal performance, public support dan fundraising efficiency terhadap tngkat kesejahteraan masyarakat diproksikan melalui Indeks Pembangunan Manusia (IPM). Objek penelitian ini adalah BAZNAS Pusat yang terletak di Jalan Kebon Sirih Raya No.57, Jakarta, kode pos 10340, Indonesia.

Data penelitian ini menggunakan jenis data kuantitatif, yaitu total pendapatan (perolehan dana), total aset, total kontribusi, total biaya penghimpunan dana dan total biaya untuk mendapatkan dana ZIS pada BAZNAS yang didapatkan dari website resmi BAZNAS Pusat (pusat.baznas.go.id). Data diperoleh dari publikasi laporan keuangan tahunan BAZNAS yang telah di audit. Selanjutnya data kesejahteraan masyarakat diambil dari dokumen terpublikasi oleh website resmi BPS (bps.go.id). Data sekunder dalam penelitian ini merupakan jenis data dalam bentuk deret waktu Time Series dengan menggunakan rentang waktu tahun yaitu dari 2001 sampai dengan 2020 dari masing-masing variabel.

Penelitian ini menganalisis hasil estimasi dari presentase tingkat kesejahteraan masyarakat sehingga kita dapat mengetahui pengaruh variabel bebas terhadap variabel terkait dalam penelitian, regresi dalam pengolahan data akan menggunakan regresi berganda dan menggunkan metode Ordinary Least Square (OLS) menggunakan metode analisis Regresi linier berganda. Sebelumnya, dilakukan uji asumsi klasik untuk memberikan kepastian bahwa persamaan regresi yang di hasilkan memiliki ketepatan dalam estimasi, tidak bias dan konsisten. Selanjutnya dilakukan $u j i \mathrm{t}$ dan $u j i \mathrm{f}$ untuk melihat pengaruh variabel independent $(X)$ terhadap variabel dependent $(Y)$. Adapun pengolahan data pada penelitian menggunakan Eviews 12 .
Secara sistematis persamaan regresi dirumuskan sebagai berikut:

$Y i=\alpha+\beta 0+\beta 1 X 1+\beta 2 X 2+\beta 3 X 3+e i$

(1)

Dimana :

Y :Presentase Tingkat Kesejahteraan Masyarakat

a : Konstanta

b1 : Koefisien regresi untuk X1

b2 : Koefisien regresi untuk X2

b3 : Koefisien regresi untuk X3

$\mathrm{X} 1$ : Fiscal Performance

X2 : Public Support

X3 : Fundrasing Efficiency

\section{HASIL DAN PEMBAHASAN}

Uji normalitas dilakukan engan Jarque-Bera Test, diamana melihat hasil nilai probabilitas Jarque-Bera. Jika diperoleh nilai probabilitas Jarque-Bera lebih besar dari tingkat signifikansi $((\alpha=5 \%$ atau 0,05), maka model regresi berdistribusi normal.

Tabel 2

Hasil Uji Normalitas

\begin{tabular}{ll}
\hline Jarque-Bera & 2.792231 \\
Probability & 0.247557 \\
\hline
\end{tabular}

Tabel diatas menjukkan bahwa probablitas Jarque-Bera sebesar 0.247557 . Sehingga dapat dikatakan bahwa nilai probabilitas lebih besar dari taraf signifikan $(\alpha=5 \%)$ yang berarti tidak signifikan, ini menunjukkan bahwa residualnya berdistribusi normal.

Heteroskedastisitas dilakukan dengan melihat nilai probabilitas ChiSquare pada Obs* ${ }^{\star}$-square. Model regresi dikatakan terbebas dari masalah heterokedastisitas apabila nilai probabilitas Chi-Square lebih besar dari tingkat signifikansi ( $\alpha=5 \%$ atau 0,05$)$.

$$
\begin{aligned}
& I P M=1.832097-0.012472 \_F P+ \\
& 0.015025 \_P S+0.012345 \_F E(2)
\end{aligned}
$$


Tabel 3

Hasil Uji Heteroskedastisitas

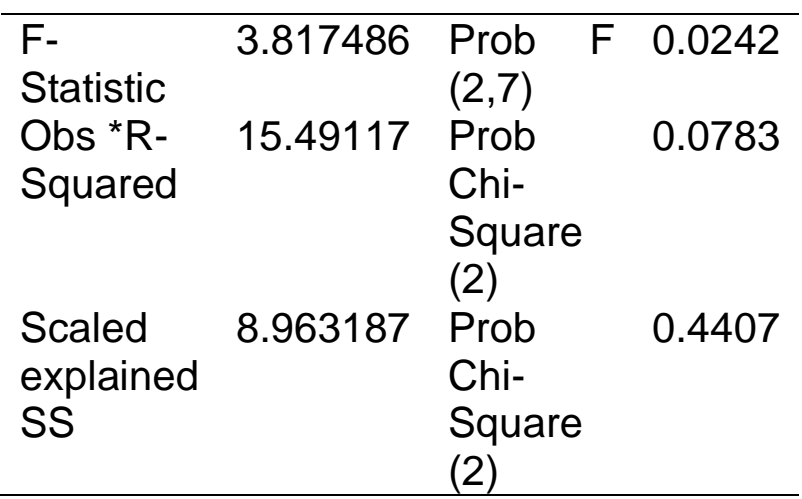

Sumber : Data diolah Eviews 12, 2021

Tabel 3 menunjukkan hasil nilai probabilitas Chi i-Square pada Obs* Rsquare adalah sebesar 0.0783. Hasil tersebut lebih besar dari tingkat signifikansi yang berarti bahwa model regresi tidak terkena heteroskedastisitas.

Analisis pengaruh kinerja keuangan dengan variabel rasio fiskal performance, public support dan fundraising efficiency terhadap presentase tingkat kesejahteraan masyarakat di Indonesia tahun 2001-2020, maka diperoleh hasil sebagai berikut :

Tabel 4

Hasil Uji Regresi Linear Berganda

\begin{tabular}{llll}
\hline $\begin{array}{l}\text { Variabl } \\
\text { e }\end{array}$ & $\begin{array}{l}\text { Coefficie } \\
\mathrm{nt}\end{array}$ & $\begin{array}{l}\mathrm{t}- \\
\text { statistic }\end{array}$ & Prob \\
\hline $\mathrm{C}$ & 1.83209 & 69.694. & 0.000 \\
& 7 & 05 & 0 \\
X_INF & - & - & 0.495 \\
X2_PS & 0.01247 & 0.69697 & 8 \\
X3_FE & 2 & 3 & 0.393 \\
& 0.01502 & 0.87736 & 3 \\
& 5 & 7 & 0.461 \\
& 0.01234 & 0.75395 & 8 \\
& 5 & 0 & \\
\hline
\end{tabular}

Sumber : Data diolah Eviews 12, 2021

Dari hasil analisis dan pengolahan daa dalam penelitian ini dengan jumlah data yaitu 20 tahun dari tahun 2001-2020, diperoleh hasil pengolahan pada tabel diatas. Hasil pengolahan Eviews tersebut dapat dilihat persamaannya sebagai berikut:
Hasil pengolahan data diperoleh nilai koefisien determinasi (R2) sebesar 0.074299 artinya, bahwa variabel tingkat kesejahteraan masyarakat dapat dijelaskan oleh variabel penjelas yakni variabel kinerja keuangan yang meliputi fiscal performance, public support dan fundraising efficiency yakni di pengaruhi sebesar 74,29 \% sedangkan 25,71 \& dijelaskan oleh variabel lain diluar variabel tercantum dalam penelitian ini.

Tabel 5

Hasil Uji F Statistic

\begin{tabular}{ll}
\hline F-statistic & 0.428065 \\
Prob (F-statistic) & 0.735640
\end{tabular}

Sumber : Data diolah Eviews 12, 2021

Nilai $F$ tabel pada dengan $d f$ numerator $(k-1)=3$, dan df denominator ( $n$ $\mathrm{k})=16$, maka dapat diperoleh nilai $F$ tabel sebesar 3,24 untuk nilai $F$ hitung diperoleh sebesar 0, 428065 Dapat disimpulkan bahwa $\mathrm{F}$ hitung lebih kecil dari $\mathrm{F}$ tabel. Sedangkan menurut nilai probabilitas hasil regresi diperoleh probabilitas $\mathrm{F}$ adalah 0,735640 lebih besar dari $\alpha=5 \%$, artinya secara bersama-sama variabel independen belum mampu berpengaruh signifikan terhadap variabel dependen.

\section{PEMBAHASAN}

Sukarela dari muzaki dan dana tetap dari APBN melalui kementerian agama belum mampu meningkatkan kesejahteraan melalui pendayaagunaan zakat maksimum. Secara teori kenaikan rasio dukungan publik menyebabkan penyaluran zakat naik dan tingkat kesejahteraan naik. Hal ini tidak sejalan dengan (Ayu et al., 2017; Nurzaman, 2011, 2017; Rithie \& Kolodinsky, 2003; Sanders, 2008; Wahab et al., 2016). Penelitian dari (Ezza et al., 2018) menunjukkan hasil yang sejalan dengan penelitian ini. Hal ini dikarenakan LPZ belum mampu melakukan penyaluran zakat. Selain itu masyarakat belum memiliki rasa kepercayaan terhadap LPZ penyebabnya LPZ belum mampu menunjukkan keseriusan dalam mengelola zakat yang 
tercerminkan melalui kinerja keuangan yang sehat.

Berdasarkan Hasil pengolahan data diatas dapat diketahui bahwa nilai t tabel uji satu sisi dengan derajat kebebasan hitung untuk variabel Fundraising Efficiency sebesar 0.753950 dengan probabilitas 0,4618 , sedangkan t tabel sebesar 1,74588 dimana nilai $\mathrm{t}$ hitung $<\mathrm{t}$ tabel, maka $\mathrm{HO}$ diterima dan Ha ditolak. Oleh karenanya variabel Fundraising Efficiency tidak berpengaruh secara statistik terhadap variabel tingkat kesejahteraan masyarakat Indonesia. Hal ini menggambarkan dan yang dikeluarkan LPZ (BAZNAS) untuk sosialisasi dan edukasi terhadap muzaki untuk mendapatkan dana zakat berpengaruh positif namun tidak signifikan. Dalam hal ini BAZNAS masih mengeluarkan biaya yang lebih guna mengoptimalkan penghimpunan. Penjelasan ini tidak sejalan dengan (Ayu et al., 2017; Beik, 2009; Nurzaman, 2011, 2017; Rithie \& Kolodinsky, 2003; Sanders, 2008; Wahab et al., 2016). Adapun penelitian sejalan dilakukan oleh (Ezza et al., 2018) Semakin efisiensi LPZ dalam mengalokasikan biaya untuk menghimpun dana turut menjadi pertimbangan masyarakat dalam berzakat. Rasio ini menunjukkan semakin tinggi nilai efisensi program yang dilakukan maka minat masyarakat dalam berzakat lebih besar pula.

Nilai $f$ tabel pada dengan $d f$ numerator $(\mathrm{k}-1)=3$, dan df denominator ( $\mathrm{n}$ $\mathrm{k})=16$, maka dapat diperoleh nilai $\mathrm{F}$ tabel sebesar 3,24 untuk nilai $F$ hitung diperoleh sebesar 0, 428065 Dapat disimpulkan bahwa $\mathrm{F}$ hitung lebih kecil dari $\mathrm{F}$ tabel sehingga menerima $\mathrm{HO}$ dan menolak $\mathrm{Ha}$. Sedangkan menurut nilai probabilitas hasil regresi diperoleh probabilitas $\mathrm{F}$ adalah 0,735640 lebih besar dari $\alpha=5 \%$ maka menolak $\mathrm{Ha}$ dan Menerima HO artinya secara bersama-sama variabel independen belum mampu berpengaruh signifikan terhadap variabel dependen. Artinya, Variabel Kinerja keuangan BAZNAS yang terdiri dari rasio Fiscal Performance, Public Support \& Fundraising Efficiency belum mampu secara bersamaan mempengaruhi tingkat kesejahteraan masyarakat. (Nurzaman, 2017) dalam penelitiannya menjelaskan variabel produktif zakat berkorelasi positif dengan tingkat IPM. Ini menyiratkan bahwa semakin zakat produktif dapat diberikan semakin kaya penerimanya.

Namun, dibutuhkan sejumlah besar zakat untuk mencapai hasil positif ini. Karena masih ada kesenjangan besar antara realisasi dan potensi pendapatan zakat oleh LPZ di Indonesia Perlu usaha tidak hanya dari zakat lembaga tetapi juga dari pemerintah untuk menyediakan peraturan dan lingkungan yang menguntungkan. Kesadaran masyarakat juga diperlukan untuk membayar zakat melalui zakat lembaga agar pembiayaan terkelola dengan baik untuk disalurkan kepada mustahiq.

\section{SIMPULAN DAN SARAN}

Berdasarkan hasil analisi dan pembahasan dapat diambil kesimpulan sebagai berikut : BAZNAS sebagai salah satu organisasi nirlaba belum memiliki kinerja keuangan yang baik, hal ini sangat disayangkan karena, Zakat memberikan peran strategis dalam meningkatkan kesejahteraan, mengurangi kesenjangan, dan menekan kemiskinan. Untuk itu perlu adanya kebijakan-kebijakan relevan yang mampu mendorong laju pertumbuhan zakat ke arah yang lebih baik, sehingga tujuan-tujuan tersebut dapat terealisasikan serta terwujud dengan baik.

Hasil uji t-statistik menunjukan bahwa tidak ada pengaruh yang siginifkan antara Pengaruh Kinerja Keuangan BAZNAS (Fiscal Performance, Public Support \& Fundraising Efficiency Terhadap Kesejahteraan Masyarakat Indonesia pada 2001-2020.

Hasil regresi diperoleh probabilitas $F$ adalah 0,735640 lebih besar dari $\alpha=5 \%$ maka menolak $\mathrm{Ha}$ dan Menerima $\mathrm{HO}$ artinya Variabel Kinerja keuangan BAZNAS yang terdiri dari rasio Fiscal Performance, Public Support \& Fundraising Efficiency belum mampu secara 
bersamaan mempengaruhi tingkat kesejahteraan masyarakat.

\section{DAFTAR PUSTAKA}

Achiria, D. R. dan S. (2018). Implementasi Keadilan dalam Pembangunan Ekonomi Islam, (2015), 53-68.

Arwani, A., \& Wahdati, A. (2020). The Effect of Zakat, Infak, Sedekah (ZIS), Human Development Index and Unemployment on Indonesia's Economic Growth, 5(2), 159-173. Retrieved from https://doi.org/10.21093/at.v5i2.2220

Ayu, D., Cahya, N., \& Achmad, T. (2017). Analisis Pengaruh Reputasi Organisasi dan Kinerja Keuangan Terhadap Kontribusi Organisasi Nirbala. Diponegoro Journal of Accounting, 6(3), 606-614.

Azwari, P. ., Rijal, K., Safitri, N., \& Saputra, R. (2019). The Financial Performance Measurement Model Modification Using Tools of Ritchi Kolodinsky and International Zakat Standard of Management (ISZM). International Conference of Zakat, 137-159. Retrieved from https://doi.org/10.37706/iconz.2019.1 49

Bahri, E. ., Romantin, M., \& Lubis, A. . (2017). Analisis Kinerja Keuangan Lembaga Zakat (Studi Kasus: Badan Amil Zakat Nasional). Perisai: Islamic Banking and Finance Journal, 1(2), 96-116. Retrieved from https://doi.org/10.21070/perisai.v1i2.8 82

BAZNAS. (2020). Fikih SDGS.

Beik, S. . (2009). Analisis Peran Zakat dalam Mengurangi Kemiskinan: Studi Kasus Dompet Dhuafa Republika. Jurnal Pemikiran Dan Gagasan.

Djuwarijah, D. (2008). Peningkatan Kualitas Sumber Daya Manusia Melalui Pendidikan Islam. El-Tarbawi, 1(1), 13-26. Retrieved from https://doi.org/10.20885/tarbawi.vol1.i ss1.art2

Eko, S., Aslam, M., \& Harun, A. (2017). Zakat and SDGs: Impact Zakat on
Human Development in the Five States of Malaysia. International Journal of Zakat, 2(1), 61-69.

Ezza, A. ., S, D. ., \& Setiawan. (2018). Penurunan Persentase Kemiskinan Sebagai Dampak Kinerja Keuangan Organisasi Pengelola Zakat Di Indonesia. Research Workshop.

Haron, M. S., \& Rahman, R. (2016). Pengagihan Zakat Dalam Konteks Kesejahteraan Masyarakat Islam: Satu Tinjauan Berasaskan Maqasid Al-Syari'Ah. Labuan E-Journal of Muamalat and Society, 10, 129-140.

Khasandy, E. ., \& Badrudin, R. (2019). The Influence of Zakat on Economic Growth and Welfare Society in Indonesia. Integrated Journal of Business and Economics, 3(1), 65. Retrieved from https://doi.org/10.33019/ijbe.v3i1.89

Lazuardy, A., Sarumpaet, S., \& Sukmasari, D. (2017). An Evaluation of Indonesian Environmental Non-Profit Organisations' Financial Performance (An Empirical Study on World Wildlife Fund Indonesia.

Murniati, R, \& Beik, I. . (2014). Pengaruh Zakat Terhadap Indeks

Pembangunan Manusia dan Tingkat Kemiskinan Mustahik: Studi Kasus Pendayagunaan BAZNAS Kota Bogor. Al-Muzara'ah, 2(2), 135-149. Retrieved from https://doi.org/10.29244/jam.2.2.135149

Murniati, Rina, \& Beik, I. S. (2014). Pengaruh Zakat terhadap Indeks Pembangunan Manusia dan Tingkat Kemiskinan Mustahik: Studi Kasus Pendayagunaan BAZNAS Kota Bogor. Al-Muzara'ah, 2(2), 135-149. doi:10.29244/jam.2.2.135-149

Ningrum, J. W., Khairunnisa, A. ., \& Huda, N. (2020). Pengaruh Kemiskinan, Tingkat Pengangguran, Pertumbuhan Ekonomi dan Pengeluaran Pemerintah Terhadap Indeks Pembangunan Manusia (IPM) di Indonesia Tahun 2014-2018 dalam Perspektif Islam. Jurnal IImiah Ekonomi Islam, 6(2), 212. Retrieved 
from

https://doi.org/10.29040/jiei.v6i2.1034

Nurzaman, S. . (2011). Zakat and Human Development: An Emirical Analysis on Poverty Alleviation in Jakarta, Indonesia 1. International Conference on Islamic Economics and Finance, 126.

Nurzaman, S. . (2017). The Impact of Zakat Programs From Human Development Perspectives: An Empirical Evaluation. Dental Nursing, 13(5), 232-233. Retrieved from https://doi.org/10.12968/denn.2017.1 3.5.232

Prihastuti, A. . (2018). Pengaruh Alokasi Belanja Modal dan Pertumbuhan Ekonomi Terhadap Indeks Pembangunan Manusia di Kabupaten/Kota Riau. Jurnal Menara, 4(1), 1-8.

Purbaningsih, Y. . (2021). The Effect of Income Distribution, Human Development Index, And Economic Growth on Poverty. International Journal of Economic and Business Applied, 1(2), 187-194.

Rithie, W. ., \& Kolodinsky, R. . (2003). Nonprofit Organization Financial Performance Measurement: An Evaluation of New and Existing Financial Performance Measures. Nonprofit Management and Leadership, 13(4), 367-381. Retrieved from https://doi.org/10.1002/nml.5

Sanders, K. (2008). An Analysis Of Florida Public Community College Foundations' Performance Measures From 2002-2004.

Sekeenah Anuar, F., Mohd, A. N., \& Ariffin, N. . (2019). Financial Management Practices and Performance of Zakat Institutions in Malaysia. Financial Management Practices and Performance of Zakat Institutions in Malaysia IPN Journal of Research and Practice in Public Sector Accounting and Management, 9(1), 1-26.

Sodiq, A. (2016). Konsep Kesejahteraan Dalam Islam. Equilibrium, 3(2), 380405.
Statistik, B. P. (2020). Indeks Pembangunan Manusia.

Suprayitno Eko, Mohamed Aslam, \& Azhar Harun. (2017). Zakat and SDGs: Impact Zakat on Human Development in the Five States of Malaysia. International Journal of Zakat, 2(1), 61-69.

Suradi. (2017). Pembangunan manusia, kemiskinan dan kesejahteraan sosial. Jurnal Penelitian Dan Pengembangan Kesjahteraan Sosial, 12(3), 1-11.

Wahab, N. ., \& Rahim, A. (2011). A framework to analyse the efficiency and governance of zakat institutions. Journal of Islamic Accounting and Business Research, 2(1), 43-62. Retrieved from https://doi.org/10.1108/17590811111 129508

Wahab, N. ., Zainol, Z., Bakar, M. ., Ibrahim, A. ., \& Minhaj, N. (2016). Developing Service Quality Index for Zakat Institutions. International Journal of Economics and Financial, 6(7), 249-258. 